\title{
SITI: JAVANESE'S BELIEFS AS THE REPRESENTATION OF GENDER ROLES AND INEQUALITIES TOWARDS WOMEN'S POSITION
}

Siti: Kepercayaan Jawa Sebagai Representasi Peran dan Ketidaksetaraan Gender terhadap Posisi Wanita

\author{
Fransiska Rahayu Myrlinda \\ Universitas Kristen Petra Surabaya \\ Myrlinda15@gmail.com
}

Naskah diterima: 27 Maret 2019; direvisi: 28 Juni 2020 disetujui: 28 Juni 2020

doi: https://doi.org/10.26499/jentera.v9i2.1358

\begin{abstract}
Being males and females is biologically constructed since human beings were born. Meanwhile, there is also strict distinction done by society to divide people into men and women or usually called as doing a gender stereotype. It results in different assumptions that are attached to them. People are categorized based on their own gender roles in society. Java, as the symbol of patriarchal society, is the ethnic which contributes the social effects of this phenomenon. Its beliefs symbolize how men and women have different social status. Furthermore, it conveys different gender roles between men and women. SITI is the film which deals with this phenomenon. It showed that being "obedient" Javanese women gives effect on social status towards different genders. The theories of Javanese culture, sex and gender, and also patriarchal society were used to get the reliable data of this research.
\end{abstract}

Keywords: SITI, Patriarchal society, Inequality, Javanese's beliefs

\begin{abstract}
Abstrak
Menjadi pria dan wanita secara biologis dibangun sejak manusia dilahirkan. Sementara itu, ada juga perbedaan mendalam yang masyarakat lakukan untuk membagi manusia menjadi pria dan wanita atau biasa disebut sebagai stereotip di gender. Hal ini berpengaruh pada perbedaan asumsi yang melekat padanya. Sebagai akibatnya, manusia dikategorikan berdasarkan peran gender mereka sendiri di masyarakat. Jawa, sebagai simbol masyarakat patriarki, adalah etnis yang berkontribusi dalam pengaruh sosial dari fenomena ini. Kepercayaan yang ada pada masyarakat Jawa melambangkan bagaimana pria dan wanita memiliki status sosial yang berbeda. Lebih lanjut, hal ini juga berdampak pada peran gender yang berbeda di masyarakat. SITI adalah film yang merepresentasikan fenomena ini. Film ini menunjukkan bahwa sebagai perempuan Jawa yang "taat" memberi efek pada status sosial dari gender yang berbeda. Teori budaya Jawa, seks dan gender, serta budaya masyarakat patriarki digunakan untuk mendapatkan data yang sesuai.
\end{abstract}

Kata-kata Kunci: SITI, Budaya Patriarki, Ketidaksetaraan, Kepercayaan Jawa

How to Cite: Myrlinda, Fransiska Rahayu. (2020). Siti: Javanese's Beliefs as The Representation of Gender Roles and Inequalities Towards Women's Position. Jentera: Jurnal Kajian Sastra, 9(2), 187-198. doi: https://doi.org/10.26499/jentera.v9i2.1358 


\section{INTRODUCTION}

In our society, people usually differentiate sex as males and females. Sex is a given word to symbolize biological connection between one person and another. Ruth A. Wienclaw, as she written in the book Sociology Reference Guide: Gender Roles and Equality, describes the characteristics of being females and males that differ people according to their sexes. Females are defined by having two $\mathrm{X}$ chromosomes. Meanwhile, males are those who have both $\mathrm{X}$ and Y chromosomes at once (2011:34).

On the other hand, there is also a term called gender that divides people into some categorization. The word gender is usually used by the society to describe people as men and women. Gender refers to psychological, social, cultural, and behavioral characteristics in connection with what sex they belong to be, either they are males or females. Gender is not something we are born with, and not something we have, but something we do (West and Zimmerman, 1987)-something we perform (Butler, 1990). Gender is a part of one's identity and self-concept (Salem Press, 2011: 39). It results on sex, or usually called as biological aspect, has effect on differentiating people according to their gender. With this strict distinction, it is completely impossible, for example, a man to bear a child except he acts only as an observer.

Categorizing people as men and women or it can be called as doing gender stereotype is the easiest way for the society to create the different status between them. Men and women have certain fixed roles in society. Until the late of 1990s, women were put in the second place, while men were in the first place (Davies, 2004, p.304). Because of their reproductive roles, women are stated as home and heart keepers. Meanwhile, men are protectors and providers since they are categorized based on their size and strength. As the result, it gives an assumption that becoming men is superior to women.

Men are symbolized as strong, fast, aggressive, dominant, and achieving. Meanwhile, women are sensitive, intuitive, passive, emotional, and interested in the things of home and family. Men's roles are outside of home. They can earn money from the job or profession they have. On the other hand, women's roles are in home. They do not have high school education and never held jobs. It builds up a stereotype that women cannot live without men. Women are often symbolized as those who always need guidance or protection from men. It gives effect on the status they have in society. Women have lower status than men in the society and even in the all aspects of living. 
Java is one of the ethnics in Indonesia which completely agrees with this social phenomenon. People of Java or usually called as Javanese people maintain the beliefs that people do differ according to their gender, whether they are categorized as women or men. By socialization, Javanese people with different genders learn to give meaning between which one is acceptable or unacceptable to be done and how to react according to society. It begins immediately after they were born. Gender roles are socially constructed and taught through the socialization process.

Moreover, Javanese culture as the culture of the Javanese ethnic group in Indonesia supports this kind of phenomenon. This theory elaborates the explanation of a Javanese's family condition in their habitual life. Javanese culture coveys high influences to the development of gender roles. Koentjaraningrat (1990) stated that Javanese culture gives meaning to the relation between husband and wife. A wife then has to show respect towards her husband (ngajeni) as the husband is always assumed to be older than his wife. The wife's sphere of interest centers mainly on the household. The husband is the household head, but he mostly has to concern himself with external matters, such as fulfilling the family's needs ad usually takes little interest in the day-to-day household routine. He only gives his wife a certain amount of money at fixed periods, within which his wife has to run the household for the entire period. The husband is also the only one who can decide everything that his family needs to be done.

Furthermore, Javanese's beliefs argue that men are the ones who have power in household. Men are the leader of the family. Men are those who play as managerial and instrumental roles by earning money according to their chosen profession. Men need to be aware that they have responsibility to support the family. They are told that real men do not cry. They are able to control their soft emotions (Salem Press, 2011, p.35). It is the men's roles to be the role model in every part of living.

Meanwhile, women portray different position than men. In a household, women should be the superordinate, while men are supposed to be the head. Women play expressive roles, such as taking care of home and emotional life of a family. Women are told not to fight. Women are believed to not showing their anger or being aggressive in public. Even when they are still children, they are given girl toys such as dolls, kitchen tool play, and others with which the most important thing is to play and to learn socially approved. According to Javanese traditional belief, the role of women is to become wife, mother, or support person (Goldberg, 1977, p.22). Parsons argued that becoming a full-time mother is responsible for 
the family needs, while father or husband is responsible for income (Salem Press, 2011, p.66). Women are limited to their roles as wives and mothers.

SITI is an Indonesian film that reflects the fact that gender roles and inequalities happen in Javanese society. Indonesian film entitles SITI produced by Ifa Isfansyah, Fourcolours Films house of production. Eddie Cahyono is the director of this film. He is also the one and only script writer who have an idea to publish this film. Drama is a genre that wants to be evoked by creating this film. The dialogues in this film are all in the form of Javanese language. SITI is the black and white film nominated as best Indonesian Film in many international film festivals, such as Singapore, Shanghai, Taiwan, and Toronto Reel Asian International Film Festivals in around 2014 until the late of 2015. This film is firstly released on public on January 28, 2016. This film takes 88 minutes as its duration. This film showed the representation of being an "obedient" Javanese woman, gender roles and inequalities toward the position of woman.

There are lots of famous actors and actresses play in this film, such as Sekar Sari, Haydar Saliz, Titi Dibyo, Delia Nuswantoro, Ibnu Widodo, Chelsy Bettido. SITI is the film about a 24 years old woman named Siti, played by Sekar Sari, who needs to take care for her whole family. Living with Darmi (her mother-in-law), Bagus (her sick husband), and Bagas (her son), she is the one who has high responsibility to control everything. Her life has terribly changed when her husband, Bagus, got an accident a previous year before when he was in the sea for fishing. It gives effect on his health. He no longer has the ability to walk by himself. Bagus's new boat also lost at the same time when the accident happened.

The case in film SITI is very unusual in our patriarchal society where Siti, as the representation of woman in Javanese culture, has more steady and high-standard paid job than Bagus. This film is a reflection of how society seems to change the normal belief in Javanese into something new, especially in the position of different gender roles between men and women. Women, who usually act as stay-at-home persons and take care of household, completely change their roles in this film. When women even become the breadwinner of the family, the subordination still happens. Women are still portrayed as the victim of the men. It then raised a question regarding the issue of whether or not it is possible to switch the position while women are conveyed as the breadwinner while men become stay-at-home husbands. The women then are those who need to play as the head of the family and control everything around them. 
SITI is a film that reflects how patriarchy is the effective way in differentiating people according to their gender. Patriarchy is defined as "any system of organizational (political, economic, industrial, financial, religious, or social) in which the overwhelming numbers of upper positions in hierarchies are occupied by males (Goldberg, 1977, p.25)." Patriarchy is the term used to imply male domination in conveying power over women. Father or fatherfigure holds authority over women and children. Sylvia Walby (1990) claimed the definition of patriarchy as a system of interrelated social structures which allow men to exploit women. Women employ as passive victims of oppression. They have to struggle against the exploitation if they want to survive.

In family relationship, Steven Goldberg added that the concept of patriarchy is seen as male dominance where man or husband has power over woman or wife. "Whereas patriarchy refers to hierarchical realities, male dominance refers to male-female encounters and relationships, to the "feeling" acknowledged by the emotions of both men and women that general authority in dyadic and familial relationships, in whatever terms a particular society defines authority, ultimately resides in the male (1973, p.37).” Delmarrich Bilga Ayu Permatasari's journal also supported this idea. She stated that discrimination will always be the result of dominance done by husband to his wife. Patriarchy becomes the system which never let women to fight for their rights. No matter how hard the efforts they have tried, women could not do anything against inequalities.

Patriarchy is still strongly dominating the society nowadays. SITI conveys the fact that patriarchy does exist in Javanese's family, especially in the family relationships and different gender roles between men and women. It shows how a man, especially the husband's figure, dominates the control in a family. On the other hand, the woman, as the representative of wife, only has limited power in the family. She cannot stand in her own feet to state her feelings. She would rather obey what her husband wanted them to do instead of confessing her desire in the family.

Patriarchy has existed in our society for ages. Most of the times people seem do not realize it because they see it as something natural and even they have never questioned about it. When women overpower men, it affects the relationship between them. The film SITI tries to describe how patriarchy is applied in Javanese's beliefs as the important aspect to see how different genders would convey different roles in family. Moreover, the film also shows how patriarchy conveys the fact that men performed the main roles in family according to the Javanese's belief. Patriarchy is clearly seen on the ways Siti's husband exert their power 
during the life that Siti needs to deal with. The film reveals the fact that women have lack of power compare to the men. Siti, as the representation of a wife, tends to fight against her husband's desire especially the one which is related to the agreements about making decisions and earning money. Instead of doing nothing, she prefers to earn money and becomes the breadwinner.

Thus, in this research, the researcher is intended to analyze how the Javanese beliefs represent and the aspects that evoke inequalities between genders which seen through Indonesian film entitles SITI. Textual research is used to support the data in this research. The data were all taken from Indonesian film entitles SITI. Data collection methods were varied, including document collection and observations. Javanese culture and patriarchy are reliable theories to see how the film tries to fight against the beliefs that women should stay at home and need to deal with inequalities.

\section{THE REPRESENTATION OF JAVANESE'S BELIEFS IN FILM SITI}

In film SITI, Javanese's beliefs are the tools used to support the issue in the film. Javanese's beliefs are varied. It affects the life of people who deal with it especially the life of Javanese people itself.

\section{a. Man is superior to woman}

In SITI, the Javanese's belief in gender role after marriage relationship between Siti and Bagus is changing. With Siti as the breadwinner in the family, it places Bagus not as the head of the family but as the subordinate. It is different with the Javanese's belief that commonly happen in Javanese society.

Becoming the breadwinner in the family, Siti is supposed to be the head that controls the income of family needs. Meanwhile, this condition places Bagus as the husband has the role of a house-husband who needs to do things such as cooking, cleaning, maintaining the home, and taking care of their children. The question then comes up whether or not it is suitable with Javanese's belief. From the observation in film SITI, it can be seen that the answer is no. There are several evidences to show that doing house-husband is not suitable with Javanese's belief.

Being a subordinate husband in the family means the man should accept being controlled by his wife. However, it is not suitable with Javanese's belief. Javanese's belief argues that no matter happens in the family, it is the man who has the power over woman. 
Woman should be inferior to man. It can be seen in the film that even Bagus as the husband still struggles against the fact that Siti as his wife is superior to him. Bagus still struggles to have that power over his wife, especially in every argument they have. In the raising action of the film, for example, when Siti tries to show her power that she is the one who has control of everything and Bagus replies with no reaction. Besides the fact that he is palsy, he keeps in silent and reacts nothing when Siti wants to talk about every single thing happens in their family. Bagus prefers to remain silent whenever Siti asks for his argument.

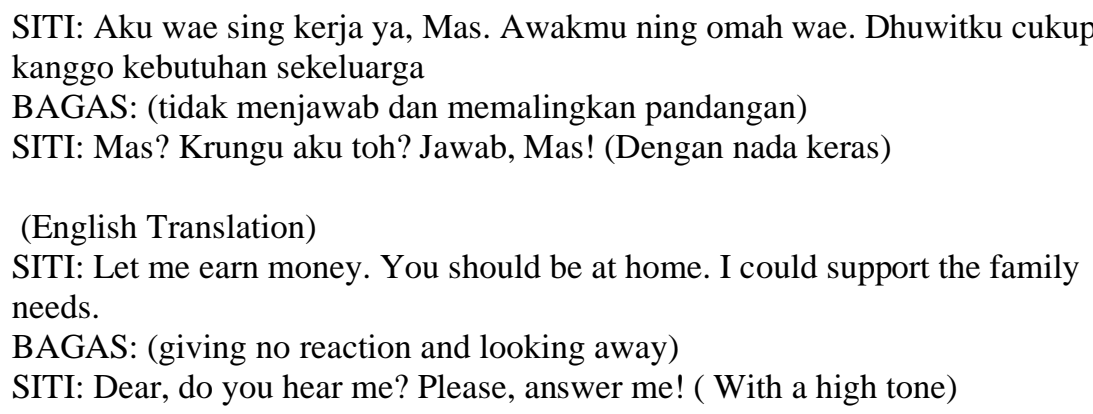

It happens several times in the film that Bagus tries to maintain his position as superior over his wife, Siti. Even though the fact that he is no longer able to walk by himself is true, he wants to show that he is still able to control the family. His disability does not affect his position as the head of the family. Even from the beginning of the story until almost the end of the film, for example, Bagus as the representation of the husband performs that he does not give permission for his wife to have a job and go to work.

\section{b. Woman's place is at home}

Indonesian film entitles SITI shows the different places where people belong to according to their gender. A man should have a job and go to work, while woman should stay at home and taking care of the household. Bagus, for example, by pretending to not able to speak he wants to declare that women do not have a right to get a job. Woman's place should only be at home. He does not want to argue with his wife about her decision to have job while he himself stays at home.

With his flat-face expression to Siti, for example, whenever she asks about his opinion becoming a dangdut singer, it can be implied that he actually wants to show a woman should only do her job as a housewife, not as the breadwinner in the family. Woman's place is only in home. Outside the house is the place of man. It is clearly stated from the dialogues between 
Siti and her best friend, Sri when they both walk passed the seashore while discussing about their life.

SRI: Lha bojomu? Nganti saiki urung gelem ngomong toh, Sit?

SITI: Ora, sejak aku kerja ning karaokean kae. Suwe-suwe ora gelem ngomong. Nesu. Embuh lah, Sri. Mumet aku. Sakjane sing nesu iki aku

SRI: Lha mbok nesu. Nesu wae kok bingung.

SITI: Ora bisa nesu aku (tersenyum)

(English Translation)

SRI: Your husband? Does he want to say something now, Sit?

SITI: No, since I work in club as time goes by he does not want to say a word. Angry, maybe. I do not know, Sri. I am confused. It should be me who do not want to talk.

SRI: Sure, go get angry if you want.

SITI: No, I cannot do that (smiling)

From the dialogues above, from Bagus's expression as the husband by not saying anything, he wants to show his wife that she is not given permission to work. Bagus forbid Siti to go out and work in order to fulfill the needs of family besides her role as wife and mother. Bagus wants to emphasize that woman should do what is acceptable according to society. There is no other place for woman except home. Meanwhile, Siti herself, as the representation of woman, does not want to fight against the belief. She just accepts her life as the way it is. She does not want to argue anything to get the equality for her rights.

\section{THE ASPECTS OF INEQUALITY BETWEEN GENDERS}

Doing the Javanese roles as showed in the film SITI implies that there is a changing value in society. Siti as the symbol of Javanese woman who acts as the way Javanese woman should be then turns out into different value in society. Historically, if women do the same ways as what the society wants, they would be categorized as good role models. It shows that doing what it is right according to Javanese's beliefs does not always have good effect for women's positions. The positions of women who do the women's roles according to Javanese's beliefs become degrading. There are three different fields which show how the positions of women are portrayed by doing what it is right to be done by Javanese women.

\section{a. In the working field}

Women who do the Javanese's beliefs as stated above are shown there is a degrading in their positions through society, especially in the working field. Women have no right to get a job and have work. Women's working fields are only in home, kitchen and bed. 
It is clearly showed in the film SITI that if women go to work and men stay at home, it results on the relationship between them. There are certain hegemony in values which one is assumed as acceptable and which one is unacceptable as stated below:

- It is acceptable for men to go to work, while women stay at home.

Film SITI represents that men have the right to get job and earn money according to their professional fields. Film SITI shows how society sees these differences for different gender roles to have a job as something common to happen in society. It can be seen from the problem happens in the main character's life, Siti. She is the one in the family who needs to go to work while her husband is unable to do it, regarding to the condition that he is palsy.

Even though Siti is the one who sacrifices her life to support her family needs, it does not change her position in the family. She remains as subordinate for her husband. Javanese's belief tries to maintain the acceptable norm that women should stay at home and not going to work. Women's place should not be outside the house. Meanwhile, her husband is supposed to be the one that is believed to go to work.

- It is also acceptable for both men and women go to work

The Javanese's beliefs are used to support the idea that it is acceptable for both women and men to go to work as long as they both have the same portion of earning money. It is used with a function to degrade the position of women in society. Women should not be paid higher than the jobs that men have. Women can go to work and earn their own money as long as they are paid less than men.

This phenomenon can be seen in the film SITI, especially in the case of Sri. Sri is Siti's best friend who can easily have access to get a job and earn money because both Sri and her husband are workers. She mentioned in the film that it is easy for her to get permission from her husband to earn her own money by doing job as a dangdut singer because she is paid less than the money that her husband can earn. She can have access to go to work and buy everything she wants. Her husband does not have any problem seeing Sri goes outside the house every single night or even knowing the fact that she is a dangdut singer who likes to seduce other men so that she can get money from it.

- It is unacceptable if men stay at home, women go to work.

Being women career while the men are inferior to them is unacceptable according to Javanese's belief. The men's places are not to stay at home. Men should not take care of the household while women can easily get a job and earn money from it. It is men's responsibility to be instrumental role by earning money from their chosen profession. 
Bagus as the representation of men shows in the film that he himself argues the same thing with this belief. He never gives a permission for Siti to go to work while he himself can do nothing and just stay at home. Being unable to walk by himself, he prefers to keep silent whenever Siti tries to discuss the topic about being a dangdut singer because it will result on the fact that he is the one who is unable to do his responsibility as the head of the family even though Siti herself does not make a problem of becoming the full-time mother and also a worker.

\section{b. In the right to speak}

Doing what it is right according to Javanese's belief does not give good effect on women. From the film, we can see that women have no right to speak, especially against men. Women who do exactly the same as what the Javanese's belief wants them to be, then turns out into something negative.

Being the "real" Javanese women, those who always do anything according to Javanese's roles, is seen as something negative. It results on the fact that society seems to judge them as 'obedient' women. They are categorized as powerless. They do not have the right to speak or even to fight against men. Even the society itself seems to give meaning to their position as passive figure since they have no right to argue on what it is suitable for them. Society seems to lead people to maintain this condition exists.

SITI describes the feelings that Javanese women want to evoke. This film tries to retells how hard the life that need to be lived by Javanese women. Javanese's belief which differentiates the roles for different genders results on giving no right for women to speak what they want to say, to fight against what they do not want to have, or even to declare what they want to be. Siti as the main character in this film plays the important role in bringing up this fact to be known by others.

Historically, doing what it is acceptable according to Javanese belief will affect positively to women because they are assumed as doing something which is sociallyapproved. On the other hand, SITI tries to show another thing which maybe forgotten by others. In the film SITI, the figure of Siti as 'obedient' women is seen as those which bring her to the lowest position in society. She is no longer able to say what she wants to say.

The degrading of women's position in having no right for women to speak especially in public sphere is shown almost in the end of the film. When Siti is proposed by Gatot, a single 
police man, but she tends to deny her own feelings just because of her status as marriedwoman. She has no right to convey her loves to Gatot because she is Bagus's wife. moreover, in the end of the film, , Siti describes herself as powerless person because of being obedient Javanese wife. When her surroundings completely against her decision to stay with Bagus, her sick husband, she could not do anything and prefer to let all things happen not according to her will.

\section{c. In cultural products}

Besides the fact that men actually also become the second victim of Javanese's beliefs, the position of women is also degrading. There is different between women and men based on gender rather than the differences in skills, abilities, or other characteristics. In cultural products, for example, women's duties are assumed only to do cooking, bearing children, and dressing up. The most important of their duties is in their relation as becoming a wife, mother, or supporting person. They should be only interested in the things of home and family. Their existences are remarkable if they are able in handling household needs. If not, then they are categorized as no one as a failed wife/mother.

\section{CONCLUSION}

Javanese's beliefs are used by society to differentiate people according to their genders. Different genders have different roles in society. These different gender roles are socially constructed and taught through the socialization process. Society seems to construct or even differentiate people from one and another as something which is naturally acceptable.

Indonesian film entitles SITI is used to show that there are some negatives effects come up toward Javanese women who always obey the Javanese women's roles in society. The identity of being good Javanese wife is lost due to the fact that they are assumed as 'obedient' women. If a Javanese woman is categorized as 'obedient' woman, it cannot be denied that their position in society also employs as powerless. They have no right to do according to their will. They need to accept which one belongs to be acceptable or unacceptable things to be done as a must.

In conclusion, being Javanese women who like to obey what it is right according to society results on degrading of women's positions. Indonesian film entitles SITI reflects the condition of Javanese women who believe and employ the Javanese's beliefs as a part of living. It is not something easy to accept the condition when the beliefs that commonly used 
as the tool to guide people to live their life peacefully turns out into the main vehicle to degrade the position of women in society. This film is also a good representation to see the fact how to react through the Javanese's beliefs which is seen in negative ways towards different genders.

\section{REFERENCES}

Bhasin, K. (1996). Menggugat patriarki, pengantar tentang persoalan dominasi terhadap kaum perempuan (terjemahan). Yogyakarta: Yayasan Bentang Budaya.

Butler, Judith. (1993). Bodies that Matter: On the Discursive Limits of "Sex". New York: Routledge.

Butler, Judith. (1990). Gender Trouble: Feminism and the Subversion of Identity. New York and London: Routledge.

Davies, Alan and Catherine Elder. (2004). The Handbook of Applied Linguistics. Malden: Blackwell Publishing Ltd.

Dennis, Rutledge M. (2005). Marginality, power, and social structure: Issues in race, class, and gender. Research in Race and Ethnic Relations, Vol 12, USA: Elsevier Ltd.

Eckert, Penelope and Sally McConnell-Ginet. (2003). Language and Gender. Cambridge: Cambridge University Press.

Geertz, H. (1961). The Javanese family: A study of kinship and socialization. New York: Free Press of Glencoe.

Geertz, Clifford. (1969). The religion of Java. New York: The Free Press.

Goldberg, S. (1973). The inevitability of patriarchy. New York: Morrow.

Koentjaraningrat. (1990). Javanese culture. Institute of Southeast Asian Studies (ISEAS): Oxford University Press, New York.

Nelson, Todd D. (2009). Handbook of Prejudice, Stereotyping, and Discrimination. New York: Psychology Press Taylor \& Francis Group.

Permatasari, Delmarrich Bilga Ayu. (2017). Resistensi Tokoh-Tokoh Perempuan terhadap Patriarki dalam Novel Garis Perempuan Karya Sanie B. Kuncoro. Jentera: Jurnal Kajian Sastra, 6(2), 94-109. DOI: https://doi.org/10.26499/jentera.v6i2.439

Salem Press. (2011). Sociology Reference Guide: Gender Roles and Equality. Pasadena, California: Hackensack, New Jersey.

Spender, Dale. (1980). Man Made Language. London: Routledge \& Kegan Paul.

Suseno, F. M. (1997). Javanese ethnics and world-view: The Javanese idea of the good Life. Jakarta: PT Gramedia Pustaka Utama.

Walby, Sylvia. (1990). Theorizing Patriarchy. Oxford: Blackwell

West, Cancade and Zimmerman, Don H., Doing Gender. (1987). "Gender and Society". In JSTOR. Vol. 1, No. 2, pp. 125-151. 